\title{
Nitrate accumulation in plants, factors affecting the process, and human health implications. A review
}

\author{
Anjana, Shahid UMAR*, Muhammad IQBAL \\ Department of Botany, Jamia Hamdard, Hamdard Nagar, New Delhi - 110 062, India
}

(Accepted 21 July 2006)

\begin{abstract}
Leafy vegetables occupy a very important place in the human diet, but unfortunately constitute a group of foods which contributes maximally to nitrate consumption by living beings. Under excessive application of nitrogen fertilizer, these vegetables can accumulate high levels of nitrate and, upon being consumed by living beings, pose serious health hazards. Therefore, efforts are warranted to minimize the accumulation of nitrate in leafy vegetables and its ingestion by human beings. This review focuses on (i) the contribution of vegetables towards dietary nitrate intake by humans, (ii) the nutritional, environmental and physiological factors affecting nitrate accumulation in plants, (iii) the harmful and beneficial effects of nitrate on human health, and (iv) the strategies that may be followed to minimize the nitrate content in plants and its subsequent consumption by human beings. The risk to human health due to nitrate consumption may be minimized by harvesting vegetables at noon, removal of organs rich in nitrate content and cooking of vegetables in water with a low nitrate content. The European Commission Regulation No. 1822/2005 needs to be followed in order to ensure safe levels of nitrate in plants for human consumption.
\end{abstract}

nitrate toxicity / nitrate reductase / spinach / human health / leafy vegetables

\section{INTRODUCTION}

The anthropogenic activities aimed at enhancing food production may facilitate accumulation of undesirable substances in plants and affect the quality of soil and water resources adversely. Excessive amounts of nitrogenous fertilizers are applied to crops, considering that it is a reasonable insurance against yield losses and their economic consequences. However, when input of nitrogen exceeds the demand, plants are no longer able to absorb it, and nitrogen then builds up in the soil, mostly as nitrates (Nosengo, 2003). This causes imbalance of nutrients in the soil and increases the nitrate level in groundwater supplies (NAAS, 2005) which influences the nitrate content of plants (Dapoigny et al., 2000; Vieira et al., 1998), especially the leafy vegetables. Nitrate has long been one of the highly emotive anions, always being talked about, whether with pride or with horror (Hill, 1999). There is conflicting evidence regarding the potential long-term health risks associated with nitrate levels encountered in the human diet. That reduction in dietary nitrate is a desirable preventive measure (Santamaria, 2006) stands undisputed.

Vegetables are the major source of the daily intake of nitrate by human beings, supplying about 72 to $94 \%$ of the total intake (Dich et al., 1996). Therefore, the European Union prescribed, almost a decade ago, the maximum limits for nitrate in lettuce and spinach, which became the foundation stone for the subsequent European Commission Regulation (No. 1822/2005). Investigations have indicated that a high nitrate accumulation in plants results in nitrite production, which is converted into nitric oxide (NO) which, together with $\mathrm{O}_{2}^{-}$, could be rapidly catalyzed by nitrate reductase into peroxynitrite $\left(\mathrm{ONOO}^{-}\right)$ which is highly toxic to plants (Durner and Klessig, 1999; Lamattina et al., 2003). Therefore, high nitrate accumulation in plants is harmful to human health (Ikemoto et al., 2002; Ishiwata et al., 2002) as well as to plant growth (Reddy and Menary, 1990).

The factors responsible for nitrate accumulation in plants are mainly nutritional, environmental and physiological. Nitrogen fertilization and light intensity have been identified as the major factors that influence the nitrate content in vegetables (Cantliffe, 1973). Diurnal changes in light intensity lead to a diurnal pattern of nitrate accumulation in plants. Many nutrients, such as chloride, calcium, potassium, sulfate and phosphorus, are involved in the nitrate accumulation process in plants. The nitrate content varies in various parts of a plant (Anjana et al., 2006; Santamaria et al., 1999) and with the physiological age of the plant (Anjana et al., 2006; Maynard et al., 1976). A reduction in nitrate content can add value to vegetable products already very popular for their nutritional and therapeutic properties (Santamaria, 2006). Therefore, it is important to adopt appropriate strategies and determine the role of individual physiological factors in the process in order to limit accumulation of nitrate in vegetables, optimize the use of fertilizer nitrogen and reduce the potential degradation of soil and water resources.

\footnotetext{
* Corresponding author: s_umar9@hotmail.com
} 
Table I. Summary of the maximum levels in European Commission (EC) Regulation No. 1822/2005.

\begin{tabular}{|c|c|c|}
\hline Product & Harvest Period & $\begin{array}{l}\text { Maximum level } \\
\left(\mathrm{mg} \mathrm{NO}_{3} / \mathrm{kg}\right)\end{array}$ \\
\hline Fresh spinach $^{1}$ (Spinacia oleracea) & $\begin{array}{l}1 \text { October to } 31 \text { March } \\
1 \text { April to } 31 \text { September }\end{array}$ & $\begin{array}{l}3000 \\
2500\end{array}$ \\
\hline Preserved, deep-frozen or frozen spinach & & 2000 \\
\hline $\begin{array}{l}\text { Fresh lettuce (Lactuca sativa L.) (protected and open-grown lettuce) } \\
\text { excluding 'iceberg'-type lettuce }\end{array}$ & $\begin{array}{c}1 \text { October to } 31 \text { March } \\
\text { - grown under cover } \\
\text { - grown in open air } \\
1 \text { April to } 30 \text { September } \\
\text { - grown under cover } \\
\text { - grown in open air }\end{array}$ & $\begin{array}{l}4500 \\
4000 \\
3500 \\
2500\end{array}$ \\
\hline 'Iceberg'-type lettuces & $\begin{array}{l}\text { Lettuce grown under cover } \\
\text { Lettuce grown in the open air }\end{array}$ & $\begin{array}{l}2500 \\
2000\end{array}$ \\
\hline $\begin{array}{l}\text { Baby foods and processed cereal-based foods for infants and young } \\
\text { children }^{2}\end{array}$ & & 200 \\
\hline
\end{tabular}

Table II. Signs and symptoms of methaemoglobinemia.

\begin{tabular}{cc}
\hline Methaemoglobin Concentration $(\%)$ & Clinical Findings \\
\hline $10-20$ & Central cyanosis of limbs/trunk; usually asymptomatic \\
$20-45$ & Central nervous system depression (headache, dizziness, fatigue, lethargy, syncope), dyspnea \\
$45-55$ & Coma, arrhythmias, shock, convulsions \\
$>70$ & High risk of mortality \\
\hline
\end{tabular}

Source: Dabney et al. (1990).

This review focuses on the contribution of vegetables towards the dietary nitrate intake, factors responsible for nitrate accumulation in plants, and the effects of nitrate on human health. It also suggests ways of minimizing the nitrate content in plants and its subsequent consumption by human beings.

\section{VEGETABLES AS A SOURCE OF NITRATE}

Vegetables, an important component of the human diet and a major source of nitrate, constitute nearly 72 to $94 \%$ of the average daily human dietary intake (Dich et al., 1996). Unfortunately, leafy vegetables grown under different agro-ecological conditions accumulate nitrate to potentially harmful concentrations. Generally, nitrate-accumulating vegetables belong to the families Brassicaceae (rocket, radish and mustard), Chenopodiaceae (beetroot, Swiss chard and spinach), Amaranthaceae (Amaranthus), Asteraceae (lettuce) and Apiaceae (celery and parsley) (Santamaria, 2006).

Nitrogenous fertilizers, mainly of the nitrate variety, are used widely in vegetable agriculture, resulting in accumulation of nitrate in plants, if the rate of its uptake exceeds the rate of its reduction to ammonium (Luo et al., 1993). As suggested by McCall and Willumsen (1998), high rates of nitrate application increase the plant nitrate content without increasing the yield. Therefore, growers who apply excessive fertilizers to ensure that nitrogen is not limiting for plant growth are unlikely to achieve any gain in terms of yield, but increase the nitrate content of crops to the levels potentially toxic to humans. Ysart et al. (1999) estimated for the adult human population a total nitrate intake of $93 \mathrm{mg} / \mathrm{day}$, normally through potatoes $(33 \%)$, green vegetables $(21 \%)$, other vegetables $(15 \%)$, beverages $(8.5 \%)$, meat products $(4.2 \%)$, fresh fruit $(3.5 \%)$, dairy $(3.1 \%)$, milk $(2.9 \%)$, miscellaneous cereals $(2.1 \%)$, bread $(1.6 \%)$ and others $(5.1 \%)$.

The European Commission (EC)'s Scientific Committee for Food (SCF) established, in 1995, the Acceptable Daily Intake (ADI) of nitrate ion as $3.65 \mathrm{mg} \mathrm{kg}^{-1}$ body weight (equivalent to $219 \mathrm{mg} /$ day for a person weighing $60 \mathrm{~kg}$ ) (SCF, 1995), whereas the Joint Expert Committee of the Food and Agriculture (JECFA) Organization of the United Nations/World Health Organization (WHO) established the Acceptable Daily Intake of nitrate as $0-3.7 \mathrm{mg} \mathrm{kg}^{-1}$ body weight (Speijers, 1996). Therefore, assuming a 60-kg body weight, ingestion of only $100 \mathrm{~g}$ of fresh vegetables with a nitrate concentration of $2500 \mathrm{mg} \mathrm{kg}^{-1}$ fresh weight exceeds the Acceptable Daily Intake for nitrate by approximately $13 \%$. For a real assessment, however, nitrate content in all other sources as well as their average daily consumption amount must be taken into account. On the other hand, the USA's Environmental Protection Agency (EPA)'s Reference Dose (RfD) for nitrate is $1.6 \mathrm{mg}$ nitrate- $\mathrm{N} \mathrm{kg}^{-1}$ body weight per day (equivalent to about $7.0 \mathrm{mg} \mathrm{NO}_{3} \mathrm{~kg}^{-1}$ body weight per day) (Mensinga et al., 2003). On November 8, 2005, the European Commission adopted EC Regulation No. 1822/ 2005 (Tab. I) and set the harmonized maximum levels for 
nitrate in lettuce, spinach, baby foods and processed cerealbased foods. The limits vary depending on the season, with higher nitrate levels permitted in winter-grown vegetables.

\section{FACTORS RESPONSIBLE FOR NITRATE ACCUMULATION}

Plant nitrate content is commonly viewed as an outcome of imbalance between its net absorption and assimilation rates (Cardenas-Navarro et al., 1999). The effect of endogenous and exogenous factors seems to be straightforward: on one hand, both uptake and assimilation systems are genetically determined (Ferrario-Mery et al., 1997; Ourry et al., 1997), explaining the variability in plant nitrate content among species and cultivars, whereas on the other hand, nitrate absorption depends on availability of nutrition, and nitrate assimilation depends independently on climate, as it is partly a photosynthetic process in many plants (Ferrario-Mery et al., 1997). Alternatively, plant nitrate content might be either fixed through osmotic potential regulation (McIntyre, 1997) or regulated per se through negative feedback on its transport systems (CardenasNovarro et al., 1999).

\subsection{Nutritional factors}

Nazaryuk et al. (2002) have studied the role of agricultural chemicals in regulating the nitrate accumulation in plants and shown that the process of nitrate accumulation depends on three major groups of factor: application of mineral fertilizers, treatment with physiologically active substances and sorbents, and the natural and anthropogenic changes in the soil environment. With respect to their impact on nitrate accumulation, these factors may be arranged in the following descending order: fertilizers $>$ physiologically active substances $>$ soil. To explore the possibility of controlling the nitrate accumulation in plant tissues, it is important to estimate the effect of an exogenous nitrogen supply on the degree of utilization of nitrogen from soil as well as fertilizers (Nazaryuk et al., 2002).

Nitrogen fertilization facilitates accumulation of nitrate in plant tissues as a result of an excess of nitrogen uptake over its reduction. When taken up in excess of immediate requirement, it is stored as free nitrate in the vacuole and can be remobilized subsequently when nitrogen supply is insufficient to meet the demand (van der Leij et al., 1998). Nitrate accumulation in vegetables often depends on the amount and kind of nutrients present in the soil and is closely related to the time of application, and the amount and composition of the fertilizers applied (Zhou et al., 2000). An adequate fertilization program may ensure sufficient plant growth without any risk of plant nitrate levels going too high (Vieira et al., 1998). Plants accumulate more nitrate as the nitrogen fertilization level increases (Chen et al., 2004; Nazaryuk et al., 2002; Santamaria et al., 1998a, b), whereas limiting the nitrogen availability reduces nitrate content significantly (McCall and Willumsen, 1999). Applying nitrogen once at the beginning of the cropping cycle is effective at controlling nitrate accumulation, since the plant and soil nitrate concentrations decrease as plants reach a marketable size (Vieira et al., 1998). The use of fertilizers based on ammonia or a mixture of nitrate and ammonium can reduce the nitrate content in plants (Inal and Tarakcioglu, 2001; Santamaria et al., 2001); it is worthy of further consideration in soilless growth systems because ammonium reduces the need for adding acids to the nutrient solution to lower its $\mathrm{pH}$ (Santamaria and Elia, 1997). Depending on which plant part is to be consumed, appropriate fertilizer can be selected (Zhou et al., 2000), e.g. the order of nitrate accumulation in the cole leaves, upon application of different nitrogenous fertilizers, is: urea $>$ ammonium carbonate $>$ ammonium nitrate $>$ ammonium sulfate; for nitrate accumulation in petioles, it is: urea $>$ ammonium nitrate $>$ ammonium sulfate $>$ ammonium carbonate.

Vegetables supplied with organic fertilizers have a low nitrate content, compared with minerally fertilized (Raupp, 1996) or conventionally grown vegetables, and this effect is independent of site conditions. Nitrate accumulation in products is a function of increasing supply of nitrate by fertilization and mineralization of soil organic matter on the one hand, and the reduced availability of assimilates on the other hand. Therefore, the higher the nitrogen availability (mineral fertilizer $>$ liquid manure $=$ slurry $>$ manure $>$ compost ) and the lower the assimilation intensity (e.g. by site conditions and season effects), the greater would be the nitrate accumulation. Moreover, the poorly controlled flux of soil nitrogen resulting from active mineralization of organic matter may lead to excessive accumulation of nitrate in plants (Nazaryuk et al., 2002).

To have a quality yield with low nitrate content is possible by manipulating the nitrogen nutrition of plants (Izmailov, 2004). Apart from nitrogen fertilization, a balanced nutrition of plants is particularly important in intensive agricultural production where high fertilizer applications are aimed at improving the yield and quality. Nutrient balance may be a critical factor affecting the nutrient status of plants (Ahmed et al., 2000). Proper application of nitrogenous, phosphate, potassium fertilizers, as well as the green and farmyard manures, could materially reduce the nitrate accumulation in vegetables (Zhou et al., 2000).

Seginer (2003) developed a dynamic lettuce model, NICOLET, for predicting plant growth and nitrate content. This was valid for the initial stage of plant growth, where composition of plants with respect to reduced nitrogen and water contents is time-invariant. The model was later modified (Seginer et al., 2004) to extend its validity to a late stage of vegetative growth to accommodate the ontogenetic changes in the reduced nitrogen and water contents. According to the modified model, prediction of nitrogen uptake for the substantial nitrate pool of lettuce depends on the water content. These models have the potential to improve the estimates of nitrogen uptake, thus leading to a more accurate calculation of fertilizer needs.

Nitrate concentration in plants can also be manipulated by stopping the nitrogen supply for some days before crop harvesting (Santamaria et al., 2001). In this way, nitrate will be removed from vacuoles and plants will guard the organic vacuoles needed to make up for the decreased osmotic value. Nitrate concentration can also be reduced by replacing nitrate$\mathrm{N}$ with chloride, sulfate, ammonium or amino acids a few days prior to crop harvesting (Inal and Tarakcioglu, 2001; Santamaria et al., 1998b).

Chloride $\left(\mathrm{Cl}^{-}\right)$and nitrate $\left(\mathrm{NO}_{3}^{-}\right)$ions play an interchangeable role in osmoregulation; the former are able to prevent 
excessive nitrate concentration by replacing the latter and may have a positive effect on nitrogen content in plant organs (Dorais et al., 2001). Interaction of chloride uptake with the uptake of nitrate and other nutrients has been reviewed by $\mathrm{Xu}$ et al. (2000). Chapagain et al. (2003) have shown that fruit nitrate decreases and chloride increases upon increasing the chloride concentration in the nutrient solution; this agrees with the earlier findings on antagonism between the chloride and nitrate uptake in plants, especially in the foliar tissues. As the total nitrogen content of plants did not decrease in response to chloride treatment, Liu and Shelp (1996) believed that chloride absorption did not compete directly with nitrate absorption. Addition of moderate amounts of chloride to the growing medium of broccoli plants decreased their nitrate content by increasing accelerating nitrate reduction. The authors suggested that chloride application could be used as a strategy to decrease nitrate content of vegetables, particularly of those such as spinach, lettuce and cabbage which are classified as nitrate accumulators (Maynard et al., 1976). However, inhibition of nitrate uptake by chloride depends on the plant species and the concentrations of both nitrate and chloride in the medium (Cerezo et al., 1997). In root cells, the high-affinity, saturable system for nitrate uptake that operates at small nitrate concentrations (Siddiqi et al., 1990) is inhibited by high external chloride, whereas the low-affinity, linear system that operates at high nitrate concentrations seems to be inhibited by internal chloride (Cerezo et al., 1997). Urrestarazu et al. (1998) have suggested that replacing nitrate with chloride in the nutrient solution during the last week before the crop harvest decreases nitrate content in leafy vegetables.

Increase in the rate of potassium application facilitates uptake and transport of nitrate towards the aerial parts of the plant, promotes the metabolism and utilization of nitrate and, ultimately, reduces nitrate accumulation in some vegetable crops (Ahmed et al., 2000; Ruiz and Romero, 2002). However, some studies have indicated that the soil potassium resources have no effect on nitrate accumulation (Drlik and Rogl, 1992).

Ahmed et al. (2000) have shown a reduction in nitrate content due to increasing phosphorus fertilization. Inorganic phosphorus within the plant is necessary for the metabolism and storage of nitrate, but high concentrations inhibit enzyme reactions, create abnormal pressure in the cell, and accelerate senescence, and the advancing plant age is accompanied by a reduced nitrate uptake and accumulation (Ahmed et al., 2000). Growth reduction associated with limiting phosphate results in increases in the root-shoot ratio, dry matter content, concentrations of sugars and organic acids, and reduction in the concentration of nitrate in the shoots (Buwalda and Warmenhoven, 1999).

Nitrate accumulation has also been studied in relation to some other chemicals. Foliar application of salicylic acid (Ahmed et al., 2000), molybdenum fertilizers (Zhou et al., 2000) and nitrification inhibitors (Xu et al., 2005; Zhou et al., 2000) and calcium (Tzung et al., 1995) can materially reduce the nitrate content of plants. In lettuce leaves sugar levels and free amino acid concentrations increase under high supply of calcium and replace nitrate in the vacuole of the lettuce cell (Ahmed, 1996). There exists a negative correlation between nitrate content and sulfate content in the lettuce plant (BlomZandstra and Lampe, 1983) and, therefore, sulfur deficiency might lead to an increase in nitrate content (Maynard et al., 1976). The contents of nitrate in most crops (cabbage, carrot, beet, tomato, onion and potato) decreased significantly under the influence of humic acid as well as zeolite (Nazaryuk et al., 2002).

A supply of boron in concentrations that were either deficient or just sufficient for the plant's normal metabolism did not affect the nitrate content, but the toxic boron rate significantly increased the nitrate content of plants (Inal and Tarakcioglu, 2001). Cultivation of vegetables on soil contaminated with sewage sludge may also lead to accumulation of nitrate in edible plant parts due to very high levels of soil nitrogen caused by the sludge (Nazaryuk et al., 2002).

Accumulation of salt in the soils can alleviate nitrate accumulation in vegetable crops (Chung et al., 2005). Due to high fertilization and poor water supply, the water potential of the soil may become so negative that salination takes place and plants take up and accumulate nitrate as an osmoticum to adapt to water conditions. In such a situation, potassium compensates for the increased nitrate in maintaining the electroneutrality of the plant.

\subsection{Environmental factors}

Nitrate accumulation in plants is affected greatly by environmental factors. Santamaria et al. (2001) observed an interaction between light intensity, nitrogen availability and temperature on nitrate accumulation in rocket. Under conditions of low light availability, an increase in temperature increases the nitrate accumulation. Under high light intensity, an increase in temperature increases the nitrate content mainly when the nitrogen supply is high. Chadjaa et al. (2001) have studied the effect of artificial lighting in greenhouses on nitrate accumulation in lettuce. High-pressure sodium vapor lamps were more effective than metal halide lamps at increasing the nitrate reductase (NR) activity and reducing the nitrate accumulation. The effect of climate on nitrate accumulation was studied by Grzebelus and Baranski (2001), who found that nitrate content was less in the year that had a high rainfall. In warm and wet years, increased accumulation of nitrate is possible, regardless of whether the nitrogen originates from organic or mineral sources (Custic et al., 2003). Plant nitrate levels were influenced by weather conditions more significantly than by the form and application rates of fertilizers (Custic et al., 2003). Nitrate accumulation varies with the season (Vieira et al., 1998), being higher in autumn-winter than in spring (Santamaria et al., 1999). It is accepted that plants in winter are not able to use all the nitrogen available in the soil due to less favorable light and temperature conditions. Gruda (2005) has extensively reviewed the effect of different environmental factors on the nitrate content of greenhouse vegetables.

\subsection{Physiological factors}

\subsubsection{Genotypic variability}

The nitrate content varies markedly with plant species, cultivars of the same species, and even genotypes with different ploidy (Anjana et al., 2006; Grzebelus and Baranski, 2001; Harada et al., 2003). The shoot nitrate content is genetically 
determined and likely to be controlled by several genes (QTLs) (Harrison et al., 2004). The causal factors might include genetic differences among genotypes in enzymes of the nitrogen metabolic pathway (nitrate reductase/nitrite reductase), the rate of nitrate uptake, the rate of uptake of other elements needed for enzyme activity, or differences in generation of electron donors needed in the assimilative pathway that might lead to the observed variation in nitrate accumulation. In contrast, BlomZandstra and Eenink (1986) found no evidence to conclude that nitrate accumulation was caused by a low assimilation rate of nitrate in lettuce genotypes which differed significantly in nitrate content. The differing capacities of nitrate accumulation can also be correlated with differing locations of nitrate reductase activity (Andrews, 1986), and with differences in photosynthetic capacity (Behr and Wiebe, 1992), ability to generate and translocate respiratory substrate and reducing equivalents, or differences in capacity to translocate the absorbed nitrate to reduction sites. Nitrate accumulation decreases with increasing carbohydrate concentration in the vacuoles. Nitrate accumulation is negatively correlated to sugar concentrations (BlomZandstra and Lampe, 1983) and dry matter content (Reinink et al., 1987), while the latter two parameters are positively correlated to each other in different genotypes. Thus, genotypes with high dry matter content could have a high carbohydrate content in their vacuoles and thus need little nitrate to maintain their osmotic value (Reinink et al., 1987). All these factors need to be studied intensively to determine the causal factors for differences in nitrate accumulation between genotypes.

As discussed by Harada et al. (2004), studies using mutants and transgenic plants have revealed a number of genes that can affect the concentration of nitrate in a plant, e.g., genes encoding nitrate reductase (Scheible et al., 1997a), a putative anion channel, At CLC-a (Geelen et al., 2000), glutamine synthetase, and ferredoxin-dependent glutamate synthase (Hausler et al., 1994). However, other genes must also be involved. Loudet et al. (2003), using Arabidopsis Bay-O and Shahdara recombinant inbred lines (RILs), identified eight quantitative trait loci (QTLs) for nitrate content on a dry matter basis. In maize, Hirel et al. (2001) identified five quantitative trait loci for nitrate content in dry matter, one of which included a gene encoding glutamine synthetase. Nitrate storage in vacuoles is affected by multiple processes including the relative rates of nitrate uptake, nitrate reduction and assimilation, nitrate transfer to the vacuole and its export from there. Therefore, numerous gene products can potentially influence the naturally occurring variation in free nitrate levels at the whole tissue level (Harada et al., 2004).

Harrison et al. (2004) have studied genotypic variability in shoot nitrate content in Lotus japonicus and found that it was mainly due to an increase in the ion uptake regardless of biomass production. The positive correlation between the shoot nitrate content and the steady state level of mRNA encoding high-affinity nitrate transporters suggests that the higher nitrate flux is due to enhanced expression of transporters. In contrast, neither the level of nitrate reductase mRNA, nor the potential enzyme activity in vivo in the different lines was correlated with shoot nitrate content. This indicates that nitrate transport is one of the main checkpoints controlling shoot nitrate accumulation and that it is possible to lower the nitrate content through breeding strategies without affecting the biomass pro- duction. According to Harrison et al. (2004), the concept that nitrogen accumulation in crops under suboptimal nitrogen feeding conditions is highly related to crop growth rate and biomass accumulation via internal plant regulation (Gastal and Lemaire, 2002) needs to be reconsidered. It is necessary to take into account that the control of nitrate uptake and its accumulation in the plant may be subjected to genetic variability regardless of the plant's demand. This variability allows for an adaptive regulatory control mechanism depending on soil nitrate availability.

Thus, selection of genotypes that accumulate less nitrate may contribute significantly to reduction in the nitrate consumption by humans through vegetables and the subsequent risk of nitrate poisoning. Another method of circumventing the problems associated with nitrate accumulation may be to breed cultivars that do not accumulate nitrate even under heavy nitrogen fertilization.

\subsubsection{Nitrate distribution within the plant}

In general, vegetables that are consumed with their roots, stems and leaves have a high nitrate accumulation, whereas those with only fruits and melons as consumable parts have a low nitrate accumulation (Zhou et al., 2000). Nitrate content of various parts of a plant differs (Santamaria et al., 1999). Indeed, the vegetable organs can be listed by decreasing nitrate content as follows: petiole $>$ leaf $>$ stem $>$ root $>$ inflorescence $>$ tuber $>$ bulb $>$ fruit $>$ seed (Santamaria et al., 1999). In lettuce and 'head chicory', inner leaves accumulate less nitrate than outer leaves and in parsley and spinach, leaf blades accumulate less nitrate than petioles (Santamaria et al., 1999, 2001). Nitrate concentration in the petiole was more than double that in the lamina of rocket leaf (Elia et al., 2000); the difference was as high as 6.6 times greater in spinach (Anjana et al., 2006). Similarly, nitrate concentration in the petiole stems was higher than in the leaves, with the lowest in the roots in leafy vegetables (Chen et al., 2004). Therefore, increasing the blade/petiole ratio of spinach plants at harvesting (Santamaria et al., 1999) and separation of those parts of a vegetable that accumulate high nitrate concentrations, prior to processing or preparation of vegetable food, may appreciably reduce the extent of nitrate consumption by humans. Chen et al. (2004) have also shown that nitrate supply has a significant effect on nitrate distribution, both in the metabolic pool and the storage pool of leaf blades. The comparison of the nitrate storage pool with the nitrate concentration in the whole leaf (nitrate metabolic pool + nitrate storage pool) suggests that about $90 \%$ of the nitrate accumulates in the storage pool. Functional diversity of nitrate compartmentation in the cells of various species has been discussed by Izmailov (2004).

The concentration of nitrate in various plant parts could be a measure to evaluate the balance between adequate and excessive available nitrogen for optimum growth of plants during a growth season. Typically, however, this balance assumes two markedly different modes depending on the vegetable crop under consideration. Plants that develop fruit or storage organs, such as potato and tomato, usually have low nitrate-N concentrations in petioles as the crop approaches the harvest. The decline in the petiolar nitrate concentration depends on the translocation of soluble nitrogen to the developing storage 
organ, and on the gradual decrease in the available soil nitrogen. Vegetables that do not develop storage organs as the foodstuff have a different pattern of nitrate accumulation wherein nitrate often continues accumulating with the growing plant's age (Maynard et al., 1976). The findings of Anjana et al. (2006) were similar, showing that nitrate concentration in spinach was higher at later stages of plant growth. Therefore, the optimum physiological age for harvesting needs to be standardized for different leafy vegetable crops. Since nitrate continues to accumulate in spinach plants until maturity, the extent of nitrate intake by humans through spinach leaves may be reduced by harvesting the crop during the vegetative stage.

\subsubsection{Diurnal effects}

Nitrate accumulation is a complex process involving many physiological steps. Being involved in photosynthesis as well as in uptake, translocation and reduction of nitrate, the intensity of light has a crucial role in the regulation of nitrate accumulation (Merlo et al., 1994). Light intensity is inversely correlated to the nitrate content of plants; therefore, diurnal changes in light intensity might cause a diurnal nitrate accumulation pattern. The diurnal variation in nitrate content can be kept low by selecting a proper harvest time. That a high light intensity reduces nitrate accumulation has been shown in several studies (Blom-Zandstra et al., 1988; van der Boon et al., 1990). Marked diurnal patterns showing a decrease in nitrate content during the day followed by an increase during the night have also been demonstrated (Cardenas-Navarro et al., 1998; Delhon et al., 1995a, b). Various explanations, depending on the uptake and assimilation of nitrate, are put forth for the diurnal changes in the nitrate content of plants.

Nitrate uptake and accumulation: Light intensity can have a profound effect on nitrate acquisition by roots and restrict the rate of nitrate uptake in darkness (Le Bot and Kirkby, 1992). The differences in nitrate content of butterhead lettuce cultivars are due to differences in nitrate uptake (Behr and Wiebe, 1992). On the contrary, several studies have indicated that nitrate uptake does not change under dark conditions (Macduff and Wild, 1988). These discrepancies demonstrate that characterization of the effect of light intensity on nitrate uptake is still incomplete. In particular, it is not yet clear whether inhibition of net nitrate uptake in darkness results from a decreased influx (Macduff and Jackson, 1992) and/or an increased efflux (Pearson et al., 1981) across the plasmalemma of the root cells. Beevers et al. (1965) described the role of light in nitrate accumulation to be indirect in that light enhances nitrate uptake as a result of increased permeability of the tissue and this, in turn, stimulates enzymatic activity and assimilation of nitrate. There exists a strong correlation between the net uptake of nitrate by the roots and the vacuolar nitrate concentration in the leaf blades (Steingrover et al., 1986a). The increase in nitrate concentration of leaf blades during the night results from increased nitrate uptake by roots, and from reduction of nitrate to organic solutes that are metabolized in the cytoplasm. During the daytime, nitrate leaves the vacuoles partly to be replaced by soluble carbohydrates and organic acids synthesized in the light. When light is limiting, synthesis of organic acids and soluble carbohydrates declines and their role as an osmoticum is taken up readily by nitrate.
Scaife (1989) and Scaife and Schloemer (1994) have developed a model, assuming a concentration-dependent nitrate efflux in which net nitrate uptake (influx minus leakage) and nitrogen assimilation (considered as a constant fraction of the photosynthetic rate) can be calculated. This could provide precise details of the diurnal variation in nitrate uptake dependent on radiation. Another similar model assumes that nitrate influx is adjusted to reduction flux by means of a negative feedback control, which is proportional to the internal nitrate concentration (Cardenas-Navarro et al., 1998). In both these models, the internal nitrate concentration itself is involved directly in the regulation mechanism as the regulatory signal. By this hypothesis, low nitrate concentrations in plants result from an increased nitrate demand, associated with higher growth rates at high daily integrals, and correspond with a low level of feedback control over nitrate influx in the Cardenas-Navarro et al. model (1998), with a low rate of concentration-driven efflux in the Scaife model (1989). Thus, these models suggest that nitrate concentration would result from a simple proportional regulation mechanism. This hypothesis is supported by experiments in which nitrogen nutrition or assimilation was altered (King et al., 1993), and the negative correlation obtained between uptake rate and endogenous nitrate (Laine et al., 1995; Cardenas-Navarro et al., 1998, 1999). Furthermore, a direct measurement of cytosolic nitrate concentration shows that it is regulated in root cortical cells (Miller and Smith, 1996) and there is no such evidence of homeostasis of nitrate in other compartments/organs, or at the whole-plant level. The recent simulation models based on this hypothesis seem to be able to predict the whole-plant nitrate content adequately (CardenasNavarro et al., 1998).

Macduff and Bakken (2003) have provided a framework for considering diurnal co-regulation of nitrate uptake by the amino acid and nitrate levels in species assimilating nitrate predominantly in the shoots. According to this model, diurnal regulation of nitrate influx is affected by nitrate levels throughout the dark period (downregulation) and the first half of the light period (upregulation), but by amino acid levels during the second half of the light period (downregulation). The sudden light/ dark transitions affect the transpiration rate and hence xylem nitrogen flux, which in turn affects the concentration of nitrate in the cytoplasmic compartment of the roots, the rate of nitrate assimilation in the shoot and the phloem amino acid flux, once the shoot demand for amino acids associated with protein synthesis and vacuolar storage has been met.

On the other hand, according to the turgor maintenance concept, nitrate level is negatively correlated with the level of soluble, non-structural carbon compounds (SNC; mainly sugars and organic acids) as observed in lettuce and some other vegetables (Blom-Zandstra et al., 1988; Steingrover et al., 1986a, b). Veen and Kleinendorst (1985) demonstrated that nitrate and soluble carbohydrates play complementary roles in the maintenance of cell turgor. This concept was generalized by Seginer et al. (1998), who assumed that the pool size of soluble, nonstructural carbon compounds is determined by the balance between source activity (supply by photosynthesis) and sink activity (demand by growth and maintenance). They also hypothesized that a regulation mechanism adjusts the nitrate concentration to the soluble, non-structural carbon compound level according to the plant's requirements for osmotically 
active solutes to maintain turgor. This means the low summer nitrate level in lettuce is caused by the increased rate of photosynthesis at high daily integrals, which leads to accumulation of soluble, non-structural carbon compounds, thereby diminishing the need for nitrate as a cellular osmoticum. In this concept, maintaining a constant level of turgor by adjusting the nitrate concentration to fluctuating levels of soluble, non-structural carbon compounds would require a rather complex regulation. Therefore, the carbon balance, rather than nitrate homeostasis, is the primary factor that determines nitrate accumulation in lettuce (Buwalda and Warmenhoven, 1999).

Light intensity determines the production of carbohydrates and affects nitrate assimilation (by supply of NADH and induction of nitrate reductase). This may also affect the leakage of nitrate from the vacuoles (Aslam et al., 1976). Organic acids and sugars play an important role in the osmotic adjustment. There is an inverse relationship between nitrate compounds and organic compounds, suggesting that nitrate also has a role as an osmoticum, which may explain its relative unavailability for reduction in the metabolic pool (Blom-Zandstra, 1989). Concentrations of nitrate, organic acids and sugars change significantly with varying light intensity. Variation in nitrate concentration is fully compensated for by a change in the concentration of organic acids and sugars to maintain electroneutrality and osmotic pressure. At low light intensities, production of organic acids is low due to the low rate of photosynthesis (Blom-Zandstra and Lampe, 1985) and less organic compounds are thus available for storage in the vacuoles and, therefore, nitrate can serve as an alternative. This will require low energy costs, because nitrate uptake, transfer through the xylem, and storage in the vacuoles do not require as much energy, derived from ATP, as the production and accumulation of organic compounds (Lambers and Steingrover, 1978). The plant seems to shift the balance from carbohydrates to nitrate so as to maintain turgor for cell expansion during growth, and the availability of organic compounds for storage affects the need for nitrate as an osmoticum, which in turn affects nitrate uptake. Thus, the ratio between accumulation of organic compounds and accumulation of nitrate is light-dependent.

Under light-limiting conditions, assimilate production increases with increasing light intensity, which is invested in structural growth rather than in osmoregulation if nitrate is available at a higher level than is required to meet the plant's demand for reduced nitrogen. It, therefore, appears likely that increasing light intensity will result in a substantial replacement of nitrate with organic osmotica only where growth is not limited by light intensity or where nitrate availability becomes growth-limiting (McCall and Willumsen, 1999). Moreover, a negative correlation exists between nitrate accumulation and dry matter content, as reported for different genotypes (Reinink et al., 1987). It implies that when a plant accumulates nitrate as an osmoticum, it can utilize more carbohydrates for growth since the osmotic requirement is fulfilled by nitrate.

Nitrate content can be reduced significantly both by limiting the nitrogen availability and by increasing the light intensity (McCall and Willumsen, 1999). Reducing the nitrogen availability significantly reduces the contribution of nitrate to the osmotic potential and increases that of chloride, glucose and sucrose. Furthermore, contribution of nitrate to the osmotic potential becomes significantly low and that of sucrose signif- icantly high at a high light intensity. As the reduction in nitrate content with supplementary light becomes relatively slight, growth is greatly enhanced. The reduced nitrate content under high light intensity is accompanied by an increased content of sucrose, suggesting an increased rate of photosynthesis under high light intensities (McCall and Willumsen, 1999).

Nitrate assimilation and accumulation: As discussed in detail by Stitt et al. (2002), nitrogen metabolism undergoes drastic diurnal changes, which are driven by a transient imbalance between the rate of nitrogen assimilation and the rate of nitrate uptake and ammonium assimilation in the first part of the light period. It has been shown in tobacco plants growing in a high nitrate and favorable light regime that their leaves contain high levels of the NIA transcript at the end of the night. Illumination stimulates translation of the transcript and inhibits degradation of NIA protein (Kaiser et al., 1999), leading to an approximately threefold increase of NIA protein during the first hours of the light period (Scheible et al., 1997b). A rapid posttranslational activation of NIA and a high rate of nitrate assimilation are achieved during the first part of the light period. These exceed the rate of nitrate uptake by a factor of 2 (Matt et al., 2001), leading to a rapid depletion of the leaf nitrate pool. During the second part of the light period, nitrate assimilation is progressively inhibited by mechanisms that act at several levels to decrease NIA activity. These include a dramatic decrease in the NIA transcript level, which commences soon after illumination (Matt et al., 2001; Scheible et al., 1997b) and results in a decline in NIA protein and activity as well as post-translational activation of NIA after darkening (Scheible et al., 1997b). In consequence, the rate of nitrate reduction falls about twofold in the second part of the light period, and is negligible during the night (Matt et al., 2001). By contrast, nitrate uptake in the roots and movement of nitrate to the shoot remain high during the entire light period and fall by only $30 \%$ during the night. The nitrate that is taken up during the night is used almost exclusively to replenish the leaf nitrate pool (Matt et al., 2001).

Nitrate reductase activity and nitrate accumulation: It is noteworthy that during a diurnal cycle, nitrate reductase activity in leaves often decreases during the late light phase, although the sugar level in the leaves is still increasing, or at least is not decreasing (Kaiser et al., 2002). This "afternoon depression" of nitrate reductase may reflect its degradation (Man et al., 1999) and/or a block in its synthesis, and is usually paralleled by decreasing nitrate concentrations in the leaves. This effect of light is reflected in fluctuations in the carbohydrate level and in the corresponding supply of reducing equivalents (ferredoxin and NADPH). In addition, however, leaves of plants grown under low light intensity usually have low levels of nitrate reductase; the enzyme activity increases when the plants have been transferred to conditions of high light intensity. Light intensity also affects the stability of the enzyme. The rate of nitrate reduction in leaves is thus affected by light in a variety of ways.

Anjana et al. (2006) have reported that nitrate concentration was lowest at noon on a sunny day in spinach leaves. However, the time at which plants contain the lowest nitrate concentration may vary with the environmental conditions in different geographical regions of the world. Therefore, harvesting schedules need to be standardized for different geographical regions and 
the farmers advised to harvest vegetables at the recommended time of day and supply them to the market as soon as possible so that deterioration in their quality due to nitrite formation does not take place during the post-harvesting period. Moreover, by cooking vegetables in water (with low nitrate concentration), at least $50 \%$ of accumulated nitrate can be removed (Meah et al., 1994).

\section{EFFECT OF NITRATE INGESTION ON HUMAN HEALTH}

\subsection{Adverse effects}

Several human health hazards due to nitrate toxicity have been identified. The toxicity of nitrate is thought to be due to its reduction to nitrite and conversion to nitrosamines and nitrosamides through reaction with amines and amides, whose carcinogenic action is well known (Walker, 1990). The principal mechanism of nitrite toxicity is the oxidation of the ferrous iron $\left(\mathrm{Fe}^{2+}\right)$ in haemoglobin to the ferric $\left(\mathrm{Fe}^{3+}\right)$ valence state, producing methaemoglobin. As a consequence of methaemoglobin formation, oxygen delivery to human tissues is impaired (Knobeloch et al., 2000; Mensinga et al., 2003). The methaemoglobin that is formed is reduced by the following reaction:

$$
\mathrm{Hb}^{3+}+\text { Red cyt } \mathrm{b}_{5} \longrightarrow \mathrm{Hb}^{2+}+\mathrm{Oxy} \mathrm{cyt} \mathrm{b}_{5}
$$

The reduced cytochrome $b_{5}$ (Red cyt $b$ ) is regenerated by the enzyme cytochrome $b_{5}$ reductase:

$$
\text { Oxy cyt } b_{5}+\mathrm{NADH} \stackrel{\text { cyt b5 reductase }}{\longrightarrow} \text { Red cyt b + NAD. }
$$

The enzyme cytochrome $b_{5}$ reductase plays a vital role in counteracting the effects of nitrate ingestion.

The percentage of total methaemoglobin in oxidized form determines the clinical picture of oxygen deprivation with cyanosis, cardiac dysrhythmias and circulatory failure, and progressive central nervous system (CNS) effects. The CNS effects can range from mild dizziness and lethargy to coma and convulsions (Agency for Toxic Substances and Disease Registry, 2001). Clinical findings vary with methaemoglobin concentrations (Tab. II). Methaemoglobinemia, earlier believed to occur in infants only, has been reported by Gupta et al. (2000a) in people of different ages with a high nitrate ingestion, the infant and above 45 age groups being most susceptible to nitrate toxicity.

Of the total nitrate absorbed from the diet or produced endogenously, $25 \%$ is taken up by the salivary glands and secreted into the mouth (McColl, 2005). Bacteria on the dorsum of the tongue convert 10 to $90 \%$ of this nitrate in saliva into nitrite. Upon being swallowed, when the saliva meets acidic gastric juice, it is converted into nitrosating species (that is, $\mathrm{N}_{2} \mathrm{O}_{3}$ and NOSCN) and by further reacting with ascorbic acid in the gastric juice into nitric oxide (NO) (McColl, 2005), which is potentially mutagenic and carcinogenic (Iijima et al., 2003; Moriya et al., 2002). Excessive local production of nitric oxide leads to functional abnormalities associated with gastrooesophageal reflux diseases (McColl, 2005).
In the early weeks of life, before the establishment of the gastric acid barrier, the infant's gut is colonized by bacteria throughout its length and, therefore, the nitrate in the feed is readily reduced to nitrite in the stomach and small intestine by the action of bacterial nitrate reductase (E.C. 1.6.6.1). This is then absorbed and reacts with haemoglobin to form methaemoglobin; the latter greatly reduces the oxygen-binding capacity of blood and consequently, the infant's tissues are starved of oxygen and ultimately cyanosis results (Hill, 1999). In pregnant women, the level of methaemoglobin increases from the normal ( 0.5 to $2.5 \%$ of total haemoglobin) to a maximum of $10.5 \%$ at the 30 th week of gestation and subsequently declines to normal after delivery. Thus, pregnant women might be more sensitive to the induction of clinical methaemoglobinemia by nitrites or nitrates in or around the 30th week of gestation (Agency for Toxic Substances and Disease Registry, 2001).

Another concern pertains to human cancer as a result of the bacterial production of $\mathrm{N}$-nitroso compounds in the colonized hypochlorhydric stomach. N-nitroso compounds have been shown to be carcinogenic in the more than 40 animal species tested, including mammals, birds, reptiles and fish (Hill, 1999) and in humans (Michaud et al., 2004). Endogenously-formed nitrogen and oxygen free radicals are believed to be involved in human cancer etiology (Szaleczky et al., 2000). Elevated risks for cancer of the urinary bladder (Michaud et al., 2004), esophagus, nasopharynx and prostate have been reported due to high nitrate ingestion (Eicholzer and Gutzwiller, 1990). Other health problems associated with nitrate toxicity include oral cancer (Badawi et al., 1998), cancer of the colon, rectum or other gastrointestinal regions (Knekt et al., 1999; Turkdogan et al., 2003), Alzheimer's disease, vascular dementia of Biswanger type or multiple small infarct type (Tohgi et al., 1998), multiple sclerosis (Giovannoni et al., 1997), spontaneous abortion or congenital defects (Fewtrell, 2004), anencephaly (Croen et al., 2001), non-Hodgkin's lymphoma (Michal, 1998) and cardiovascular disorders (Morton, 1971).

A high percentage of acute respiratory tract infection with a history of recurrence has been reported in children consuming high nitrate content (Gupta et al., 2000b). Recurrent diarrhoea in children up to 8 years of age (Gupta et al., 2001) and recurrent stomatitis (Gupta et al., 1999) are also associated with high nitrate ingestion. It also affects the human immune system (Ustyugova et al., 2002). Some other reported effects are infant mortality, early onset of hypertension, hypothyroidism, diabetes and an adverse effect on cardiac muscles, alveoli of the lungs and adrenal glands (Gupta, 2006).

In animals, nitrate toxicity varies according to species. In general, ruminant animals develop methaemoglobinemia while monogastric animals exhibit severe gastritis (Bruning-Fann and Kaneene, 1993).

\subsection{Beneficial effects}

Various studies suggest that nitrate is harmless and rather beneficial. It has been postulated as a useful nutrient (Dykhuizen et al., 1996). Bjorne et al. (2004) have suggested that dietary nitrate may serve important gastroprotective functions. Dietary nitrate is converted into nitrite by a symbiotic relationship involving nitrate-reducing bacteria on the tongue's surface. This relationship is designed to provide a host defense against 
microbial pathogens in the mouth and lower gut (Duncan et al., 1995). The host provides nitrate, which is an important nutrient for many aerobic bacteria. In return, bacteria help the host by generating the substrate (nitrite) necessary for generation of nitric oxide in the stomach (Bjorne et al., 2004). A high concentration of nitrite present in saliva may, upon acidification, generate nitrogen oxides in the stomach (Duncan et al., 1995). Nitrite-derived nitric oxide and related compounds play an important role in gastric host defense by enhancing the aciddependent killing of swallowed pathogens (Benjamin et al., 1994; Duncan et al., 1995; Dykhuizen et al., 1996; Xu et al., 2001). The high plasma nitrate levels in patients suffering from infective gastroenteritis may protect against the faecal-oral route of reinfection via increased generation of salivary nitrite (Dykhuizen et al., 1996). According to McKnight et al. (1999), nitrate in the diet is an effective host defense against gastrointestinal pathogens. It acts as a modulator of platelet activity, gastrointestinal motility and microcirculation.

It has also been suggested that the reactive nitrosating chemistry that occurs when saliva meets acidic gastric juice may also have biological benefit (McColl, 2005). Since this chemistry possesses antimicrobial activity (Duncan et al., 1997), it appears to be primarily designed to kill pathogenic microbes entering the body via the upper gastrointestinal tract (McColl, 2005). The beneficial effects of nitrate also include reduction of hypertension and cardiovascular diseases (McKnight et al., 1999). The various effects of nitrate on human health have been covered extensively by L'hirondel and L'hirondel (2002) in their book "Nitrate and man: Toxic, harmless or beneficial?".

Thus, evidence regarding the effect of nitrate on human health is conflicting. However, in view of the large number of its harmful effects on human health, it seems reasonable to take preventive measures so as to reduce accumulation of nitrate in plants and its subsequent consumption by human beings.

\section{CONCLUSION}

Vegetables are the major source of dietary nitrate intake of humans and nitrate has many detrimental and some beneficial effects on human health. Our understanding of the specific role of nitrate and its derivatives with respect to health is incomplete, for which further studies need to be carried out. The various approaches that may be adopted to reduce nitrate levels in vegetables are summarized below:

- A balanced fertilization program for vegetable crops should be chalked out to ensure an adequate, but not excessive supply of nutrients for optimum yield and quality, and avoid or minimize nitrogen losses to the environment. The supply and release of nutrients must be in synchrony with the need of the plant. Therefore, finding out an exact adjustment of a balanced fertilizer application to nitrate uptake and reduction capability of plants should be the priority for research by agronomists. For this purpose, strategies can be evolved with simulation models. Moreover, agronomic indicators need to be implemented at farm level to provide yardsticks for nutrient management by the farmers.

- Nitrate concentration in plants may be reduced by partial replacement of nitrate in the nutrient solution with ammo- nium, urea, mixed amino acids, chloride or sulfate a few days prior to crop harvesting. Rational application of organic manure instead of inorganic nutrients, use of physiologically active substances, proper spray of nitrification inhibitors and molybdenum fertilizers, and growing plants under controlled environmental conditions may materially reduce nitrate accumulation in plants. Effects of other micronutrients and cultural conditions also need to be investigated. Selection among the available genotypes/cultivars and breeding of new cultivars that do not accumulate nitrate even under heavy fertilization may also limit human consumption of nitrate through vegetables.

- While there exists a large body of published research on strategies for reducing nitrate accumulation in plants, it remains to be translated into practice due to lack of information for farmers. Therefore, there is a need to bridge the gap between research laboratories and farmers' fields. Decision-makers must formulate relevant agricultural policies encompassing education and training of farmers to make them understand the effects of nitrate on human health and the importance of nutrient management and other strategies for minimizing the nitrate content in plant tissues. Consumers also need to be educated regarding the nitrate content in vegetables and its health implications. They must be motivated to adopt practices that help in minimizing nitrate consumption, e.g., harvesting of leafy vegetables at noon, removal of the plant organ rich in nitrate content, cooking vegetables in water containing less nitrate content, and use of fresh vegetables, etc.

- It is important to determine the exact physiological mechanism responsible for nitrate accumulation in plants. Moreover, the effect of fertilization and other cultivation practices on the physiological parameters, and their significance for enhancing crop production and quality need to be investigated. Molecular tools may be applied to reduce nitrate concentration in plants. Even though the literature suggests that genetic manipulation of activities of nitrogen assimilation enzymes may not increase yield and/or nitrogen-use efficiency of plants, we understand that overexpression of nitrate reductase genes may prove helpful in reducing the nitrate content of plants and, in consequence, improve the quality of plants for human consumption.

Therefore, an integrated collaboration among agronomists, physiologists, molecular biologists, farmers, consumers and policy-makers is the need of the hour and may yield satisfactory results towards minimizing accumulation of nitrate in plants and its subsequent consumption by human beings.

Acknowledgements: Financial support received from the Council of Scientific and Industrial Research, Government of India, is gratefully acknowledged. Thanks are due to Prof. Y.P. Abrol, Former Head, Division of Plant Physiology, Indian Agricultural Research Institute, New Delhi, for his keen interest and guidance during the preparation of this manuscript.

\section{REFERENCES}

Agency for Toxic Substances and Diseases Registry (2001) Case studies in environmental medicine: Nitrate/nitrite toxicity, US Department of Health and Human Services, Atlanta. 
Ahmed A.H.H. (1996) Physiological studies on tipburn and nitrate accumulation in lettuce plants, J. Agr. Sci. 21, 3971-3994.

Ahmed A.H.H., Khalil M.K., Farrag A.M. (2000) Nitrate accumulation, growth, yield and chemical composition of Rocket (Eruca vesicaria subsp. sativa) plant as affected by NPK fertilization, kinetin and salicylic acid, in: Proceedings of ICEHM 2000, Cairo University, Egypt, pp. 495-508.

Andrews M. (1986) The partitioning of nitrate assimilation between root and shoot of higher plants: mini review, Plant Cell Environ. 9, 511519.

Anjana, Umar S., Iqbal M., Abrol Y.P. (2006) Are nitrate concentrations in leafy vegetables within safe limits? Proceedings of the Workshop on Nitrogen in Environment, Industry and Agriculture, New Delhi, India, pp. 81-84.

Aslam M., Oaks A., Huffaker R.C. (1976) Effect of light and glucose on the induction of nitrate reductase and on the distribution of nitrate in etiolated barley leaves, Plant Physiol. 58, 588-591.

Badawi A.F., Gehen H., Mohamed E.H., Mostafa H.M. (1998) Salivary nitrate, nitrite and nitrate reductase activity in relation to risk of oral cancer in Egypt, Dis. Markers 14, 91-97.

Beevers L., Schrader L.E., Flesher D., Hageman R.H. (1965) The role of light and nitrate in the induction of nitrate reductase in radish cotyledons and maize seedlings, Plant Physiol. 40, 691-698.

Behr U., Wiebe H.J. (1992) Relation between photosynthesis and nitrate content of lettuce cultivars, Sci. Hortic. 49, 175-179.

Benjamin N., O'Driscoll F., Dougall H., Duncan C., Smith L., Golden M., McKenzie H. (1994) Stomach NO synthesis, Nature 368, 502.

Bjorne H., Petersson J., Phillipson M., Weitzberg E., Holm L., Lundberg J.O. (2004) Nitrate in saliva increases gastric mucosal blood flow and mucus thickness, J. Clin. Invest. 113, 106-114.

Blom-Zandstra M. (1989) Nitrate accumulation in vegetables and its relationship to quality, Ann. Appl. Biol. 115, 553-561.

Blom-Zandstra M., Lampe J.E.M. (1983) The effect of chloride and sulphate salts on the nitrate content in lettuce plants, J. Plant Nutr. 6 , 611-628.

Blom-Zandstra M., Lampe J.E.M. (1985) The role of nitrate in the osmoregulation of lettuce (Lactuca sativa $\mathrm{L}$.) grown at different light intensities, J. Exp. Bot. 36, 1043-1052.

Blom-Zandstra M., Eenink A.H. (1986) Nitrate concentration and reduction in different genotypes of lettuce, J. Am. Soc. Hortic. Sci. 111, 908-911.

Blom-Zandstra M., Lampe J.E.M., Ammerlaan F.H.M. (1988) C and N utilization of two lettuce genotypes during growth under non-varying light conditions and after changing the light intensity, Physiol. Plantarum 74, 147-153.

Bruning-Fann C.S., Kaneene J.B. (1993) The effects of nitrate, nitrite, and N-nitroso compounds on animal health, Vet. Hum. Toxicol. 35, 237-253.

Buwalda F., Warmenhoven M. (1999) Growth-limiting phosphate nutrition suppresses nitrate accumulation in greenhouse lettuce, J. Exp. Bot. 50, 813-821.

Cantliffe D.J. (1973) Nitrate accumulation in table beets and spinach as affected by nitrogen, phosphorus, and potassium nutrition and light intensity, Agron. J. 65, 563-565.

Cardenas-Navarro R., Adamowicz S., Robin P. (1998) Diurnal nitrate uptake in young tomato (Lycopersicon esculentum Mill.) plants: Test of a feedback based model, J. Exp. Bot. 49, 721-730.

Cardenas-Navarro R., Adamowicz S., Robin P. (1999) Nitrate accumulation in plants: a role for water, J. Exp. Bot. 50, 613-624.

Cerezo M., Garcia-Agustin P., Serna M.D., Primo-Millo E. (1997) Kinetics of nitrate uptake by citrus seedlings and inhibitory effects of salinity, Plant Sci. 126, 105-112.
Chadjaa H., Vezina L.-P., Dorais M., Gosselin A. (2001) Effects of lighting on the growth, quality and primary nitrogen assimilation of greenhouse lettuce (Lactuca sativa L.), Acta Hortic. 559, 325-331.

Chapagain B.P., Wiesman Z., Zaccai M., Imas P., Magen H. (2003) Potassium chloride enhances fruit appearance and improves quality of fertigated greenhouse tomato as compared to potassium nitrate, J. Plant Nutr. 26, 643-658.

Chen B.-M., Wang Z.-H., Li S.-X., Wang G.-X., Song H.-X., Wang X.N. (2004) Effects of nitrate supply on plant growth, nitrate accumulation, metabolic nitrate concentration and nitrate reductase activity in three leafy vegetables, Plant Sci. 167, 635-643.

Chung J.-B., Jin S.-J., Cho H.-J. (2005) Low water potential in saline soils enhances nitrate accumulation of lettuce, Commun. Soil Sci. Plant. $36,1773-1785$.

Croen L.A., Todoroff K., Shaw G.M. (2001) Maternal exposure to nitrate from drinking water and diet and risk for neural tube defects, Am. J. Epidemiol. 153, 325-331.

Custic M., Poljak M., Coga L., Cosic T., Toth N., Pecina M. (2003) The influence of organic and mineral fertilization on nutrient status, nitrate accumulation, and yield of head chicory, Plant Soil Environ. 49, 218-222.

Dabney B.J., Zelarney P.T., Hall A.H. (1990) Evaluation and treatment of patients exposed to systemic asphyxiants, Emerg. Care Q. 6, 6580 .

Dapoigny L., Tourdonnet S.D., Roger-Estrade J., Jeuffroy M.-H., Fluery A. (2000) Effect of nitrogen nutrition on growth and nitrate accumulation in lettuce (Lactuca sativa L.) under various conditions of radiation and temperature, Agronomie 20, 843-855.

Delhon P., Gojon A., Tillard P., Passama L. (1995a) Diurnal regulation of nitrate uptake in soybean plants. I. Changes in $\mathrm{NO}_{3}^{-}$influx, efflux, and $\mathrm{N}$ utilization in the plant during the day/night cycle, J. Exp. Bot. 46, 1585-1594.

Delhon P., Gojon A., Tillard P., Passama L. (1995b) Diurnal regulation of nitrate uptake in soybean plants. II. Relationship with accumulation of nitrate and asparagines in the roots, J. Exp. Bot. 46, 15951602.

Dich J., Jivinen R., Knekt P., Pentill P.L. (1996) Dietary intakes of nitrate, nitrite and NDMA in the Finish Mobile Clinic Health Examination Survey, Food Addit. Contam. 13, 541-552.

Dorais M., Papadoulos A.P., Gosselin A. (2001) Greenhouse tomato fruit quality, Hort. Rev. 26, 262-319.

Drlik J., Rogl J. (1992) The effect of graduated rates of nitrogen fertilization on yield and nitrate accumulation in carrots, Zahradnictvi 19, 39-46.

Duncan C., Dougall H., Johnston P., Green S., Brogan R., Leifert C., Smith L., Golden M., Benjamin N. (1995) Chemical generation of nitric oxide in the mouth from the enterosalivary circulation of dietary nitrate, Nat. Med. 1, 546-551.

Duncan C., Li H., Dykhuizen R., Frazer R., Johnston P., MacKnight G., Smith L., Lamza K., McKenzie H., Batt L., Kelly D., Golden M., Benjamin N., Leifert C. (1997) Protection against oral and gastrointestinal diseases: importance of dietary nitrate intake, oral nitrate reduction and enterosalivary nitrate circulation, Comp. Biochem. Phys. 118, 939-948.

Durner J., Klessig D.F. (1999) Nitric oxide as a signal in plants, Curr. Opin. Plant Biol. 2, 369-374.

Dykhuizen R., Frazer R., Duncan C., Smith C.C., Golden M., Benjamin N., Leifert C. (1996) Antimicrobial effect of acidified nitrite on gut pathogens: importance of dietary nitrate in host defence, Antimicrob. Agents Ch. 40, 1422-1425.

EC (European Commission), Commission Regulation (EC) No. 1822/ 2005 of 8 November 2005 amending Regulation (EC) No. 466/2001 as regards nitrate in certain vegetables, Official J. Eur. Union. L293, $11-13$. 
Eicholzer M., Gutzwiller F. (1990) Dietary nitrates, nitrites and N-nitroso compounds and cancer risk: A review of the epidemiologic evidence, Nutr. Rev. 56, 95-105.

Elia A., Conversa G., Gonnella M. (2000) Dosi di azoto, produzione e accumulo di nitrati di lattuga allevata in idrocoltura, Atti V Giornate Scientifiche SOI, Sirmione, 229-230.

Ferrario-Mery S., Murchie E., Hirel B., Galtier N., Quick W.P., Foyer C.H. (1997) Manipulation of the pathways of sucrose biosynthesis and nitrogen assimilation in transformed plants to improve photosynthesis and productivity, in: Foyer C.H., Quick W.P. (Eds.), A molecular approach to primary metabolism in higher plants, Taylor and Francis, London, pp. 125-153.

Fewtrell L. (2004) Drinking-water nitrate, methemoglobinemia, and global burden of disease: a discussion, Environ. Health Persp. 112, 1371-1374.

Gastal F., Lemaire G. (2002) N uptake and distribution in crops: an agronomical and ecophysiological persp., Physiol. Plantarum 53, 789 799.

Geelen D., Lurin C., Bouchez D., Frachisse J.M., Lelievre F., Courtil B., Barbier-Brygoo H., Maurel C. (2000) Disruption of putative anion channel gene AtCLC-a in Arabidopsis suggests a role in the regulation of nitrate content, Plant J. 21, 259-267.

Giovannoni G., Heales S.J.R., Silver N.C., O’Riorden J., Miller R.F., Land J.M., Clark J.B., Thompson E.J. (1997) Raised serum nitrate and nitrite levels in patients with multiple sclerosis, J. Neurol. Sci. $145,77-81$.

Gruda N. (2005) Impact of environmental factors on product quality of greenhouse vegetables for fresh consumption, Crit. Rev. Plant Sci. 24, 227-247.

Grzebelus D., Baranski R. (2001) Identification of accessions showing low nitrate accumulation in a germplasm collection of garden beet, Acta Hortic. 563, 253-255.

Gupta S.K. (2006) Nitrate toxicity and human health, Proceedings of the Workshop on Nitrogen in Environment, Industry and Agriculture, New Delhi, India, pp. 8-10.

Gupta S.K., Gupta R.C., Seth A.K., Gupta A.B., Bassin J.K., Gupta D.K., Sharma S. (1999) Epidemiological evaluation of recurrent stomatitis, nitrates in drinking water and cytochrome b5 reductase activity, Am. J. Gastroenterol. 94, 1808-1812.

Gupta S.K., Gupta R.C., Seth A.K., Gupta A.B., Bassin J.K. Gupta A. (2000a) Methemoglobinemia - A problem of all age groups in areas with high nitrate in drinking water, Nat. Med. J. India 13, 58-61.

Gupta S.K., Gupta R.C., Gupta A.B., Seth A.K., Bassin J.K. Gupta A. (2000b) Recurrent acute respiratory tract infection in areas having high nitrate concentration in drinking water, Environ. Health Persp. $108,363-366$.

Gupta S.K., Gupta R.C., Gupta A.B., Seth A.K., Bassin J.K., Gupta A. (2001) Recurrent diarrhea in areas with high nitrate in drinking water, Arch. Environ. Health 56, 369-374.

Harada H., Yoshimura Y., Sunaga Y., Hatanaka T., Sugita S. (2003) Breeding of Italian ryegrass (Lolium multiflorum Lam.) for a low nitrate concentration by seedling test, Euphytica 129, 201-209.

Harada H., Kuromori T., Horayama T., Shinozaki K., Leigh R.A. (2004) Quantitative trait loci analysis of nitrate storage in Arabidopsis leading to an investigation of the contribution of the anion channel gene, AtCLC-c, to variation in nitrate levels, J. Exp. Bot. 55, 20052014.

Harrison J., Hirel B., Limani A.M. (2004) Variation in nitrate uptake and assimilation between two ecotypes of Lotus japonicus and their recombinant inbred lines, Physiol. Plantarum 120, 124-131.

Hausler R.E., Blackwell R.D., Lea P.J., Leegood R.C. (1994) Control of photosynthesis in barley leaves with reduced activities of glutamine synthase, Planta 194, 406-417.

Hill M.J. (1999) Nitrate toxicity: myth or reality, Brit. J. Nutr. 81, 343344.
Hirel B., Bertin P., Quillere I. (2001) Towards a better understanding of the genetic and physiological basis for nitrogen use efficiency in maize, Plant Physiol. 125, 1258-1270.

Iijima K., Fyfe V., McColl K.E.L. (2003) Studies of nitric oxide generation from salivary nitrite in human gastric juice, Scand. J. Gastroentero. 38, 246-252.

Ikemoto Y., Teraguchi M., Kogayashi Y. (2002) Plasma level of nitrate in congenital heart disease: comparison with healthy children, Pediatr. Cardiol. 23, 132-136.

Inal A., Tarakcioglu C. (2001) Effects of nitrogen forms on growth, nitrate accumulation, membrane permeability, and nitrogen use efficiency of hydroponically grown bunch onion under boron deficiency and toxicity, J. Plant Nutr. 24, 1521-1534.

Ishiwata H., Yamada T., Yoshiike N., Nishijima M., Kawamoto A., Uyama Y. (2002) Daily intake of food additives in Japan in five age groups estimated by the market basket method, Eur. Food Res. Technol. 215, 367-374.

Izmailov S.F. (2004) Saturation and utilization of nitrate pools in pea and sugar beet leaves, Russ. J. Plant Physl. 51, 189-193.

Kaiser W.M., Weiner H., Huber S. (1999) Nitrate reductase in higher plants: a case study for transduction of environmental stimuli into control of catalytic activity, Physiol. Plantarum 105, 385-390.

Kaiser W.M., Weiner H., Kandlbinder A., Tsai C.-B., Rockel P., Sonoda M., Planchet E. (2002) Modulation of nitrate reductase: Some new insights, an unusual case and a potentially important side reaction, J. Exp. Bot. 52, 875-882.

King B.J., Siddiqi M.Y., Ruth T.J., Warner R.L., Glass A.D.M. (1993) Feedback regulation of nitrate influx in barley roots by nitrate, nitrite, and ammonium, Plant Physiol. 102, 1279-1286.

Knekt P., Jarvinen R., Dich J., Hakulinen T. (1999) Risk of colorectal and other gastro-intestinal cancers after exposure to nitrate, nitrite and N-nitroso compounds: A follow-up study, Int. J. Cancer 80, 852856.

Knobeloch L., Salna B., Hogan A., Postle J., Anderson H. (2000) Blue babies and nitrate-contaminated well water, Environ. Health Persp. 108, 675-678.

L'hirondel J., L'hirondel J.-L. (2002) Nitrate and man: toxic, harmless or beneficial? CABI, Wallingford, UK, p. 168.

Laine P., Ourry A., Boucaud J. (1995) Shoot control of nitrate uptake rates by roots of Brassica napus L.: Effects of localized nitrate supply, Planta 196, 77-83.

Lamattina L., Garcia-Mata C., Graziano M., Pagnussat G. (2003) Nitric oxide: the versatility of an extensive signal molecule, Annu. Rev. Plant Biol. 554, 109-136.

Lambers H., Steingrover E. (1978) Growth respiration of a flood-tolerant and a flood-intolerant Scenecio species: Correlation between calculated and experimental values, Physiol. Plantarum 43, 219-224.

Le Bot J., Kirkby E.A. (1992) Diurnal uptake of nitrate and potassium during vegetative growth of tomato plants, J. Plant Nutr. 15, $247-$ 264.

Liu L., Shelp B.J. (1996) Impact of chloride on nitrate absorption and accumulation by broccoli (Brassica oleracea var. italica), Can. J. Plant Sci. 76, 367-377.

Loudet O., Chaillow S., Krapp A., Daniel-Vedele F. (2003) Quantitative trait loci analysis of water and anion contents in interaction with nitrogen availability in Arabidopsis thaliana, Genetics 163, 711722 .

Luo J., Lion Z., Yan X. (1993) Urea transformation and the adaptability of three leafy vegetables to urea as a source of nitrogen in hydroponic culture, J. Plant Nutr. 16, 797-812.

Macduff J.H., Wild A. (1988) Changes in $\mathrm{NO}_{3}^{-}$and $\mathrm{K}^{+}$uptake by four species in flowing solution culture in response to increased irradiance, Physiol. Plantarum 74, 251-256. 
Macduff J.H., Jackson S.B. (1992) Influx and efflux of nitrate ammonium in Italian ryegrass and white clover roots: Comparisons between effects of darkness and defoliation, J. Exp. Bot. 43, 525-535.

Macduff J.H., Bakken A.K. (2003) Diurnal variation in uptake and xylem contents of inorganic and assimilated $\mathrm{N}$ under continuous and interrupted N supply to Phleum pratense and Festuca pratensis, J. Exp. Bot. 54, 431-444.

Man H.M., Abd-El Baki G.K., Stegmann P., Weigner H., Kaiser W.M. (1999) The activation site of nitrate reductase activity in leaves, Planta 209, 462-468.

Matt P., Geiger M., Walch-Liu P., Engles C., Krapp A., Stitt M. (2001) The immediate cause of the diurnal changes of nitrogen metabolism in leaves of nitrate-replete tobacco: A major imbalance between the rate nitrate reduction and the rates of nitrate uptake and ammonium metabolism during the first part of the light period, Plant Cell Environ. 24, 177-190.

Maynard D.N., Barker A.V., Minotti P.L., Peck N.H. (1976) Nitrate accumulation in vegetables, Adv. Agron. 28, 71-118.

McCall D., Willumsen J. (1998) Effects of nitrate, ammonium and chloride application on the yield and nitrate content of soil-grown lettuce, J. Hortic. Sci. Biotech. 73, 698-703.

McCall D., Willumsen J. (1999) Effects of nitrogen availability and supplementary light on the nitrate content of soil grown lettuce, J. Hortic. Sci. Biotech. 74, 458-463.

McColl K.E.L. (2005) When saliva meets acid: chemical warfare at the oesophagogastric junction, Gut 54, 1-3.

McIntyre G.I. (1997) The role of nitrate in the osmotic and nutritional control of plant development, Aust. J. Plant Physiol. 24, 103-118.

McKnight G.M., Duncan C.W., Leifert C., Golden M.H. (1999) Dietary nitrate in man: friend and foe? Brit. J. Nutr. 81, 349-358.

Meah M.N., Harrison N., Davies A. (1994) Nitrate and nitrite in foods and the diet, Food Addit. Contam. 11, 519-532.

Mensinga T.T., Speijers G.J.A., Meulenbelt J. (2003) Health implications of exposure to environmental nitrogenous compounds, Toxicol. Rev. 22, 41-51.

Merlo I., Ferretti C., Passera C., Ghisi R. (1994) Effect of decreased irradiance on $\mathrm{N}$ and $\mathrm{C}$ metabolism in leaves and roots of maize, Physiol. Plantarum 91, 72-80.

Michal F.D. (1998) A population based case control study on the association between nitrate in drinking water and non-Hodgkin's lymphoma, The Johns Hopkins University Press, USA, p. 285.

Michaud D.S., Mysliwiec P.A., Aldoori W., Willett W.C., Giovannucci E. (2004) Peptic Ulcer Disease and the Risk of Bladder Cancer in a Prospective Study of Male Health Professionals, Cancer Epidem. Biomar. 13, 250-254.

Miller A.J., Smith S.J. (1996) Nitrate transport and compartmentation in cereal root cells, J. Exp. Bot. 47, 843-854.

Moriya A., Grant J., Mowat C., Williams C., Carswell A., Preston T., Anderson S., Iijima K., McColl K.E.L. (2002) In vitro studies indicate that acid catalysed generation of $\mathrm{N}$-nitrosocompounds from dietary nitrate will be maximal at the gastro-oesophageal junction and cardia, Scand. J. Gastroentero. 37, 253-261.

Morton W.E. (1971) Hypertension and drinking constituents in Colorado, Am. J. Public Health 61, 1371-1378.

NAAS (2005) Policy options for efficient nitrogen use, Policy paper No. 33, National Academy of Agricultural Sciences, New Delhi, pp. 1-4.

Nazaryuk V.M., Klenova M.I., Kalimullina F.R. (2002)Ecoagrochemical approaches to the problem of nitrate pollution in agroecosystems, Russ. J. Ecol. 33, 392-397.

Nosengo N. (2003) Fertilized to death, Nature 425, 894-895.

Ourry A., Gordon A.J., Macduff J.H. (1997) Nitrogen uptake and assimilation in roots and root nodules, in: Foyer C.H., Quick W.P. (Eds.), A molecular approach to primary metabolism in higher plants, Taylor and Francis, London, pp. 237-253.
Pearson C.J., Volk R.J., Jackson W.A. (1981) Daily changes in nitrate influx, efflux and metabolism in maize and pearlmillet, Planta 152, 319-324.

Raupp J. (1996) Fertilization effects on product quality and examination of parameters and methods for quality assessment, in: Raupp J. (Ed.), Quality of plant products grown with manure fertilization, Darmstadt, pp. 44-48.

Reddy K.S., Menary R.C. (1990) Nitrate reductase and nitrate accumulation in relation to nitrate toxicity in Boronia megastigma, Physiol. Plantarum 78, 430-434.

Reinink K., Groenwold R., Bootsma A. (1987) Genotypical differences in nitrate content in Lactuca sativa $\mathrm{L}$. and related species and correlation with dry matter content, Euphytica 36, 11-18.

Ruiz J.M., Romero L. (2002) Relationship between potassium fertilisation and nitrate assimilation in leaves and fruits of cucumber ( $\mathrm{CuCu}$ mis sativus) plants, Ann. Appl. Biol. 140, 241-245.

Santamaria P. (2006) Nitrate in vegetables: toxicity, content, intake and EC regulation, J. Sci. Food Agr. 86, 10-17.

Santamaria P., Elia A. (1997) Producing nitrate-free endive heads: Effect of nitrogen form on growth, yield and ion composition of endive, J. Am. Soc. Hortic. Sci. 122, 140-145.

Santamaria P., Elia A., Parente A., Serio F. (1998a) Nitrate and ammonium nutrition in chicory and rocket salad plants, J. Plant Nutr. 21, $1779-1789$

Santamaria P., Elia A., Parente A., Serio F. (1998b) Fertilization strategies for lowering nitrate content in leafy vegetables: Chicory and rocket, J. Plant Nutr. 21, 1791-1803.

Santamaria P., Elia A., Serio F., Todaro E. (1999) A survey of nitrate and oxalate content in retail fresh vegetables, J. Sci. Food Agr. 79, $1882-1888$

Santamaria P., Elia A., Gonnella M., Parente A., Serio F. (2001) Ways of reducing rocket salad nitrate content, Acta Hortic. 548, 529-537.

Scaife A. (1989) A pump/leak/buffer model for plant nitrate uptake, Plant Soil 114, 139-141.

Scaife A., Schloemer S. (1994) The diurnal pattern of nitrate uptake and reduction by spinach (Spinacia oleracea L.), Ann. Bot. 73, 337-343.

SCF (Scientific Committee on Food) (1995) Opinion on nitrate and nitrite, expressed on 22 September 1995 (Annex 4 to Document III/ 5611/95), European Commission (Eds.), Brussels, p. 34.

Scheible W.-R., Lauerer M., Schulze E.D., Caboche M., Stitt M. (1997a) Accumulation of nitrate in the shoot acts as a signal to regulate shoot-root allocation in tobacco, Plant J. 11, 671-691.

Scheible W.-R., Gonzales-Fontes A., Morcuende R., Lauerer M., Geiger M., Glaab J., Schulze E.-D., Stitt M. (1997b) Tobacco mutants with a decreased number of functional nia-genes compensate by modifying the diurnal regulation transcription, post-translational modification and turnover of nitrate reductase, Planta 203, 305-319.

Seginer I. (2003) A dynamic model for nitrogen-stressed lettuce, Ann. Bot. 91, 623-635.

Seginer I., Buwalda F., van Straten G. (1998) Nitrate concentration in greenhouse lettuce: A modeling study, Acta Hortic. 456, 189-197.

Seginer I., Bleyaert P., Breugelmans M. (2004) Modelling ontogenetic changes of nitrogen and water content in lettuce, Ann. Bot. 94, 393404.

Siddiqi M.Y., Glass A.D.M., Ruth T.J., Rufty T.W. Jr. (1990) Studies of the uptake of nitrate in barley. I. Kinetics of ${ }^{13} \mathrm{NO}_{3}^{-}$influx, Plant Physiol. 93, 1426-1432.

Speijers G.J.A. (1996) Nitrate, in: World Health Organization (Eds.), Toxicological evaluation of certain food additives and contaminants in food, Food Additive Series 35, Geneva, pp. 325-360.

Steingrover E., Ratering P., Siesling J. (1986a) Daily changes in uptake, reduction and storage of nitrate in spinach grown at low light intensity, Physiol. Plantarum 66, 550-556. 
Steingrover E., Woldendorp J., Sijtsma L. (1986b) Nitrate accumulation and its relation to leaf elongation in spinach leaves, J. Exp. Bot. 37, 1093-1102.

Stitt M., Muller C., Matt P., Gibon Y., Carillo P., Morcuende R., Scheible W.-R., Krapp A. (2002) Steps towards an integrated view of nitrogen metabolism, J. Exp. Bot. 52, 959-970.

Szaleczky E., Pronai L., Nakazawa H., Tulassay Z. (2000) Evidence of in vivo peroxynitrite formation in patients with colorectal carcinoma, higher plasma nitrate/nitrite levels, and lower protection against oxygen free radicals, J. Clin. Gastroenterol. 30, 47-51.

Tohgi H., Abe T., Yamazaki K., Murata T., Isobe C., Ishizaki E. (1998) The cerebrospinal fluid oxidized NO metabolites, nitrite and nitrate, in Alzheimer's disease and vascular dementia of Binswanger type and multiple small infarct type, J. Neural Transm. 105, 1283-1291.

Turkdogan M.K., Testereci H., Akman N., Kahraman T., Kara K., Tuncer I., Uygan I. (2003) Dietary nitrate and nitrite levels in an endemic upper gastrointestinal (esophageal and gastric) cancer region of Turkey, Turk. J. Gastroenterol. 14, 50-53.

Tzung W.-J., Po W.-Y., Wu J.T., Wang Y.-P. (1995) Effects of some environmental factors on nitrate content of Chinese cabbage (Brasica chinensis L.), J. Chin. Agr. Chem. Soc. 33, 125-133.

Urrestarazu M., Postigo A., Salas M., Sanchez A., Carrasco G. (1998) Nitrate accumulation reduction using chloride in the nutrient solution on lettuce growing by NFT in semiarid climate conditions, J. Plant Nutr. 21, 1705-1714.

Ustyugova I.V., Zeman C., Dhanwada K., Beltz L.A. (2002) Nitrates/ nitrite alter human lymphocyte proliferation and cytokine production, Arch. Environ. Cont. Tox. 43, 270-276. van der Boon J., Steenhuizen J.W., Steingrover E.G. (1990) Growth and nitrate concentration of lettuce as affected by total nitrogen and chloride concentration, $\mathrm{NH}_{4} / \mathrm{NO}_{3}$ ratio and temperature of the recirculating nutrient solution, J. Hortic. Sci. 65, 309-321.

van der Leij M., Smith S.J., Miller A.J. (1998) Remobilization of vacuolar stored nitrate in barley root cells, Planta 205, 64-72.

Veen B.W., Kleinendorst A. (1985) Nitrate accumulation and osmotic regulation in Italian ryegrass (Lolium multiflorum Lam.), J. Exp. Bot. 36, 211-218.

Vieira I.S., Vasconselos E.P., Monteiro A.A. (1998) Nitrate accumulation, yield and leaf quality of turnip greens in response to nitrogen fertilisation, Nutr. Cycl. Agroecosys. 51, 249-258.

Walker R. (1990) Nitrates and N-nitroso compounds: A review of the occurrence in food and diet and the toxicological implications, Food Addit. Contam. 7, 717-768.

Xu C., Wu L.H., Ju X.T., Zhang F.S. (2005) Role of nitrification inhibitor DMPP (3,4-dimethylpyrazole phosphate) in nitrate accumulation in greengrocery (Brassica campestris L. ssp. chinensis) and vegetable soil, J. Environ. Sci. (China) 17, 81-83.

Xu G., Magen H., Tarchitzky J., Kafkafi U. (2000) Advances in chloride nutrition of plants, Adv. Agron. 68, 97-150.

Xu J., Xu X., Verstraete W. (2001) The bactericidial effect and chemical reactions of acidified nitrite under conditions simulating the stomach, J. Appl. Microbiol. 90, 523-529.

Ysart G., Miller P., Barrett G., Farrington D., Lawrance P., Harrison N. (1999) Dietary exposures to nitrate in the UK, Food Addit. Contam. $16,521-532$.

Zhou Z.-Y., Wang M.-J., Wang J.-S. (2000) Nitrate and nitrite contamination in vegetables in China, Food Rev. Int. 16, 61-76. 